Grzegorz Godawa

Pontifical University of John Paul II in Krakow, Poland

\title{
A child's loneliness in the family as a challenge for modern pedagogy
}

\begin{abstract}
The problem of loneliness has become more and more common in society. It affects the family which is a place of physical and spiritual closeness. A child's isolation in the family is related to many factors. It may be caused by the parents' emotional indifference or the child's serious illness. The disturbances may be painful for the child who often cannot fight the sense of isolation. Attempts to counteract the sense of loneliness are connected with pedagogical action. It should be based on permanent values which extend the scope of support offered to the family. Strengthening the family system makes it possible to overcome the child's sense of loneliness.
\end{abstract}

\section{Keywords}

loneliness, child, family, support, illness.

The most characteristic feature of family life is physical and spiritual closeness of the family members. This concept of family reveals a considerable potential for good and hope which family members can benefit from. Children, in particular, benefit from the atmosphere in the family. The atmosphere of love enhances their development ${ }^{1}$. The potential of the family is fulfilled unless there are factors that disrupt family life. The modern family is continuously subject to influences which may distort its development in spite of the progress made towards facilitating its functioning. Consequently, the physical and spiritual closeness of the family members may give way to feelings of isolation and loneliness.

1 B. Lachowska, Szczęśliwe dzieciństwo - uwarunkowania rodzinne, in: Oblicza dzieciństwa, D. Kornas-Biela (ed.), Lublin 2001, KUL, p. 275. 
A child's loneliness in the family does not seem to be the most severe kind of isolation as it is much more difficult for the child to be completely deprived of the family environment ${ }^{2}$. The phenomenon of a child's loneliness in the family is not widely recognized by educators. Hence, it requires a more thorough analysis which would show the complexity of the issue. It is essential to highlight the meaning of loneliness, its causes and signs, as it will allow modern pedagogy to formulate postulates which may eventually improve the current situation.

\section{Loneliness and isolation}

The definition of loneliness in the Dictionary of the Polish Language shows the subjective understanding of this notion, describing it as "experiencing the state of the lack of company of a close person and the state of being abandoned by others"3. A lonely person is "living alone, without family or friends, is completely alone in a particular situation or over a period of time"4. But as well as having the internal dimension related to one's experiences, loneliness may have an external and objective dimension which can be verified.

From one psychological point of view, we may say that loneliness is "the condition of a person who lives alone"s. However, such a simple definition does not seem to describe this complex phenomenon adequately. The psychological approach which presents loneliness as withdrawal and isolation of an individual is more detailed: "Loneliness is felt by a wide range of [members in] society on a regular basis - there is no one reason which causes the feeling or emotion of loneliness, but it is commonly associated with depression and lack of a social life" 6 . This definition emphasises that there are a lot of reasons why people experience loneliness.

J. Rembowski discusses five ways of understanding the experience of loneliness: the psychodynamic one, in which loneliness is a dynamic and

2 M. Bukowska, Zagadnienie samotności we wspótczesnej polskiej literaturze naukowej, Kraków 2008, MCDN, p. 30.

3 Samotność, in: Stownik języka polskiego, www.sjp.pl (08.01.2014).

4 Samotność, in: Słownik języka polskiego PWN, www.sjp.pwn.pl (08.01.2014).

5 Samotność, in: N. Sillamy, Słownik psychologii, Warszawa 1995, Książnica, p. 260.

6 Loneliness, in: Psychology dictionary, www.psychologydictionary.org (09.01.2014). 
pathological force; the phenomenological one, in which one's experiences are the reason for loneliness; the existential one, which assumes that people are lonely by nature and can find power in loneliness; the interactionist one, which analyses loneliness on the level of emotions or social relationships, and the cognitive one, which assumes that the way of perceiving the reasons for loneliness, in particular the lack of social contacts, influences the experience of loneliness? .

In the pedagogical approach loneliness is a condition which manifests itself in three crucial aspects and embraces social, psychological, and moral loneliness ${ }^{8}$. All of the above categories contribute to the understanding of the notion of loneliness, but psychological loneliness, one's personal and inner experience, requires special attention. It is often described as isolation: "Isolation, that is psychological loneliness, concerns the feelings of an individual, their sensitivity and needs. It consists in inadequate psychological contact with another person despite his/her physical presence, which causes the disruption of inner harmony, psychical discomfort, and the sense of marginalisation within the family or another social group".

In the classical approach presented by C. Tarnogórski, loneliness differs from isolation because people are aware of choosing the latter one. Hence, isolation may not be considered solely as suffering: "A lonely person often observes other people's lives more carefully, notices events and problems which are not seen by people who are busy with their 'everyday life' and who do not have the time to reflect on others" ${ }^{10}$. Isolation which is self-imposed does not generate so many negative emotions and has another meaning. Therefore, it may be assumed that "a lonely person does not have to be isolated, but they may be isolated despite not living alone"

The notion of isolation expresses the feelings of a child struggling with the sense of being separated from others more adequately than the concept

\footnotetext{
J. Rembowski, Samotność, Gdańsk 1992, UG, p. 25-26.

8 J. Gajda, Samotność, in: Encyklopedia pedagogiczna XXI w., T. Pilch (ed.), vol. 5, Warszawa 2006, Żak, p. 652.

9 T. E. Olearczyk, Sieroctwo i osamotnienie. Pedagogiczne problemy kryzysu współczesnej rodziny, Kraków 2010, WAM, p. 95.

${ }^{10}$ C. Tarnogórski, Wobec samotności i osamotnienia, in: Samotność i osamotnienie, M. Szyszkowska (ed.), Warszawa 1988, IWZZ, p. 4.

${ }^{11}$ C. Tarnogórski, Wobec samotności..., op. cit., p. 5.
} 
of loneliness ${ }^{12}$. Therefore, it is crucial to extend the understanding of causes and signs of the child's isolation. It is worth highlighting that the child may experience isolation in all kinds of upbringing environments; within the family, at school, among peers, in the local community, or in front of the computer ${ }^{13}$. The most basic environment is constituted by the family which tends to be associated with love and warm feelings. The experience of isolation among blood relatives is therefore more acute for the child.

\section{A child's isolation in the family}

There are many reasons why a child experiences difficult feelings connected with the unsatisfied need to be close to another person, e.g. the lack of any emotional bond between the child and the parents, an autocratic upbringing, a disturbed system of prizes and punishments, the birth of younger siblings, a lack of time for the child, family arguments, divorce, family reconstruction, illness or disability ${ }^{14}$, pathology in the family, or the low social status of the family ${ }^{15}$. It should be emphasized that the above mentioned factors which determine the child's isolation do not have to occur all at the same time. Their influence on experiencing psychological loneliness may also vary.

The social environment and the child's individuality should also be taken into consideration while discussing the topic, as there are particular groups of children who are vulnerable to the experience of isolation, e.g. children with early developmental disorders, children who are often ill in early childhood, children who do not show signs of secure attachment, children who show signs of disoriented attachment, children of dependent or avoidant mothers, or children who have gone through traumatic events ${ }^{16}$. The variety of factors proves that the issue under discussion is very complex, and it is not possible to discuss all the factors in this article. Thus, the analysis needs to be limited

12 J. Izdebska, Samotność dziecka, in: Encyklopedia pedagogiczna ..., op. cit., p. 657.

${ }^{13}$ M. Bukowska, Zagadnienie samotności..., op. cit., p. 27.

${ }^{14} \mathrm{~J}$. Stala, Rozpoznanie u początku prawidłowej pomocy - charakterystyka osób z niepetnosprawnościa intelektualna, in: Socjalizacja - wyzwanie wspótczesności, J. Stala (ed.), Tarnów 2010, Biblos, p. 446-448. p. $28-31$.

${ }^{15}$ R. Pawłowska, E. Jundziłł, Pedagogika człowieka samotnego, Gdańsk 2000, GWSH,

${ }^{16}$ Z. Dołęga, Dzieci zagrożone samotnościa, in: Oblicza dzieciństwa..., op. cit., p. 503. 
to a few factors which cause isolation. The parents' emotional indifference and the child's illness will be discussed in the article, as these factors seem to have a lot to do with the issue of upbringing. Furthermore, a model of counteracting emotional deprivation will be constructed.

\section{a. Parents' emotional indifference and the sense of isolation}

Parents who are emotionally indifferent pose a threat to the child's social and emotional development because they do not satisfy the child's needs, and, furthermore, they shape a particular behaviour which may impede the child's proper socio-emotional functioning: "Indifferent parents try to do whatever is necessary to minimize the time and energy that they must devote to interacting with their child. In extreme cases, indifferent parents may be neglectful. They know little about their child's activities and whereabouts, show little interest in their child's experiences at school or with friends, rarely converse with their child, and rarely consider their child's opinion when making decisions"17.

The attitude of parents who do not recognize their child's emotional needs is the main reason why the child feels isolated, since "the most important thing which the parent may give to the child is love, attention and happiness because of being together in various situations" ${ }^{\text {"18. }}$. Lack of time devoted to the child intensifies its sense of low self-esteem. The child discovers that there are more important matters than his or her problems and, as a consequence, becomes shy and insecure while building relationships with others. It then becomes very easy to escape into the isolated world of difficult emotions.

Assuming that negative attention is better than none, the child strives to get it. This mechanism sometimes becomes the source of extreme behaviour towards the parents. The child may be "far too obedient and disciplined, or just the opposite: its behaviour may be inappropriate and troublesome because it thinks that in this way the parents will pay attention to it. Emotional emptiness is so acute that it may lead to the serious states of apathy and social isolation"19. Emotional emptiness, which means lack of love and interest in the child's problems, causes a sense of unfairness, rebellion and isolation in the child.

17 L. Steinberg, Parenting, in: www.education.stateuniversity.com (09.01.2014).

18 A. Błasiak, Oddziaływania wychowawcze w rodzinie. Zagadnienia wybrane, Kraków 2012, WAM, p. 116.

19 R. Pawłowska, E. Jundziłł, Pedagogika człowieka..., op. cit., p. 29. 
The situation when the child was not planned and did not gain its parents' attention after birth may be particularly painful. It is widely believed that the moment of first contact is the most important for the shaping of the bond between the newborn child and its mother ${ }^{20}$. However, the time spent together later is actually more significant. The inability to build secure attachments makes the child feel sad and isolated more and more often ${ }^{21}$.

\section{b. Influence of illness on the sense of isolation}

The child's illness is one of the most destructive events which may occur in his or her life: "Illness is one of the least desired phenomena in the child's life, since it distorts both development and health as the child's crucial needs remain unsatisfied." 22 The temporary nature of illnesses which small children often go through does not cause tensions as strong as those caused by chronic illnesses: "Changes that are 'permanent' in the child's psychological life most often accompany chronic illnesses. These are illnesses which last for a long time (sometimes a few years, or even the whole life)"23. Chronic illness may be regarded as a stress factor, the source of frustration and need deprivation, a traumatic phenomenon, and a very difficult event in the process of the child's development ${ }^{24}$.

The small patient identifies closely with the family environment. The family ensures the basic care and social bonds needed in the process of development. The sense of closeness to the significant people in one's surroundings and their willingness to help are both relevant, since people outside the family environment are unable to provide the child with the same. The need to communicate which the child feels from the very first years of its

${ }^{20}$ Z. Dołęga, Dzieci zagrożone..., op. cit., p. 502.

${ }^{21}$ According to the report prepared by the British organisation NSPCC, in the course of 12 months (April 2008 - March 2009) more than 9000 children called their hotline for help with problems which were directly or significantly related to their sense of isolation. The research showed that in the course of 10 years the number of children asking for help in fighting loneliness has grown by almost $20 \%$. In: National Society for the Prevention of Cruelty to Children, Children talking to ChildLine about loneliness, ChildLine Casenotes 2010, www.nspcc.org.uk (09.01.2014).

${ }^{22}$ B. Ziółkowska, Dziecko chore $w$ domu, w szkole i u lekarza. Jak wspomagać rozwój dzieci przewlekle chorych, Gdańsk 2010, GWP, p. 45.

${ }^{23}$ A. Maciarz, Psychoemocjonalne $i$ wychowawcze problemy dzieci przewlekle chorych, Kraków 2001, IMPULS, p. 21.

${ }^{24}$ A. Maciarz, Psychoemocjonalne $i$ wychowawcze problemy dzieci przewlekle chorych, op. cit., p. 16-18. 
life undergoes transformations during the subsequent stages of development, especially while facing external factors such as illness. Illness isolates the child in a specific way. The ill child may feel isolated from its peers and be convinced that he or she is the only one who is ill among them, which intensifies the sense of confusion.

Chronic illness isolates the child not only because of the risk of distorting the process of development, but at times also because of the inability to come into contact with the external world which may result from the nature of the illness, or the stage it has reached. The child's loneliness may also be intensified by communication problems which are caused by his or her inability to express emotions: "Even when opportunities are offered to children to talk about their experiences, this may still prove too difficult, as the behaviour of carers may reveal the emotional sensitivity of particular topics, and children may wish to protect their carers from any distress or upset. It is often equally important to be as sensitive to what is left unsaid as to what is said. In addition, children may be so overwhelmed, confused, or distressed by their feelings that it is not possible for them to express those feelings in words or developmentally they may not have the ability or they may have not acquired the vocabulary necessary to do so" 25 .

Moreover, the child's sense of isolation is painful because of his or her failure to overcome the condition without other people's assistance. This is often impeded by the child's not knowing enough about the mechanisms of the illness and not being able to deal with difficulties due to lack of experience ${ }^{26}$. In spite of the presence of family members, the child may still experience a sense of isolation and struggle with the lack of understanding it undergoes, even in a loving family.

\section{Counteracting isolation in a pedagogical way}

Modern pedagogy has to face these challenges, and requires adjusting its methods to the social needs. Action should focus on attempting to reduce the

${ }^{25}$ T. Aasgaard, M. Edwards, Children expressing themselves, in: Oxford Textbook of Palliative Care for Children, A. Goldman, R. Hain, S. Liben (eds.), New York 2012, Oxford University Press, p. 100.

${ }^{26}$ A. Maciarz, Dziecko przewlekle chore. Opieka i wsparcie, Warszawa 2006, Żak, p. 9. 
negative effects of the inappropriate behaviour of the child's family, and on developing the appropriate patterns of behaviour. Hence, the support offered to the child and its family becomes a form of influencing the family and the child ${ }^{27}$.

The therapeutic programme which may be beneficial to the family and the child should be based on permanent values. The family, perceived as a community and as one of the most basic values, should again become the place of development ${ }^{28}$. This becomes possible if the family truly values love, truth, responsibility, and dialogue in everyday life. A constant revision of the quality of interactions between the family members is needed. These interactions should make it possible for the family members to discover the beauty and the good in the family. According to Pope Benedict XVI, "Christianity, Catholicism, is not a collection of prohibitions: it is a positive option. It is very important that we look at it again because this idea has almost completely disappeared today. We have heard so much about what is not allowed that now it is time to say: we have a positive idea to offer, [...] it is in this way that marriage develops, first of all, as a joyful and blessing-filled encounter between a man and a woman, and then, as a family" ${ }^{\prime 2}$. The positive view of the family, despite the difficulties which it has to struggle with, is a condition which facilitates its development.

It is necessary to recognize the very value of the child being born: "In a functional family, the child knows that it was born as a valuable person, it does not lack anything" ${ }^{30}$. The child is convinced that the love of parents is unconditional, and should not lock himself or herself in an isolated world because the parents do support the child in difficult moments. The key to gaining emotional and communicative competence is sincere love of the child and the ability to show empathy, which, "as a specific kind of communication, may prevent conflicts, aggression and other negative behaviour"31.

${ }^{27}$ B. Matyjas, Źródła prowadzace do osamotnienia dziecka $w$ rodzinie, in: Wychowanie w rodzinie. Rodzina o specjalnych potrzebach, S. Walasek, B. Winczura (eds.), Jelenia Góra 2011, wyd. KPSW, vol. 4, p. 136.

${ }^{28}$ J. Mastalski, Samotność globalnego nastolatka, Kraków 2007, PAT, p. 493-516.

${ }^{29}$ Wywiad Benedykta XVI: pozytywna Ewangelia rodziny (18.08.2006), in: www.radiovaticana. va (12.01.2014).

${ }^{30} \mathrm{~S}$. Kawula, Rodzina o skumulowanych czynnikach patogennych, in: Pedagogika rodziny. Obszary i panorama problematyki, S. Kawula, J. Brągiel, A. W. Janke (eds.), Toruń 2007, Adam Marszałek, p. 149.

${ }^{31}$ P. Modzelewski, Emocjonalna więź, empatyczna komunikacja - w stronę wysokiej jakości życia w rodzinie, in: Prawne, administracyjne i etyczne aspekty wychowania w rodzinie, S. Bębas, 
The family perceived as the place of development of its members fulfills the educational function that is one of the most basic elements of its activity ${ }^{32}$. Parents, who are responsible for the process of upbringing, may experience a lot of contradictory emotions: "Parenthood and child rearing is a responsible duty performed over the course of one's whole life. It gives happiness and satisfaction, but can also cause stress, anxiety, and a sense of helplessness" ${ }^{\prime 3}$. Illness is one of the stress factors which may occur in family life, and it is particularly painful when it affects the child. In such a situation, the educational influence which will give the child a chance to develop is particularly needed, remembering that "every caring situation, regardless of its specificity, should have the character of educational care, that is care which will allow the child to develop in accordance with the educational patterns adopted by the family and the society" 34 . Such an approach to the child's illness enables the family to prevent the destructive influence of illness. It also makes it possible to counteract the sense of isolation the child might experience.

John Paul II wrote that "in the family, which is a community of persons, special attention must be devoted to the children by developing a profound esteem for their personal dignity, and a great respect and generous concern for their rights. This is true for every child, but it becomes all the more urgent the smaller the child is, and the more it is in need of everything, when it is sick, suffering, or handicapped"35. The care provided for the child through the duties mentioned by the Pope enables the child to overcome the difficulties which it has to face. At the same time, the relationships between the family members can be strengthened.

The family is not always able to overcome the difficulties related to the child's illness without help from the outside. Therefore, there is a postulate to reinforce the social support which may help to fight the crisis. One of

E. Jasiuk (eds.), Radom 2011, WSH, vol. 1, p. 233-234.

${ }^{32}$ S. Kawula, Rodzina jako grupa i instytucja opiekuńczo-wychowawcza, in: Pedagogika rodziny..., op. cit., p. 59.

${ }_{33}$ A. Błasiak, Obszary, możliwości i potrzeby pedagogicznego wspomagania rodziny $w$ dzisiejszej rzeczywistości, in: Dokąd zmierzasz współczesna rodzino?, M. Duda, A. Świerczek (eds.), Kraków 2012, Św. Stanisława BM, p. 338.

${ }^{34}$ P. Krakowiak, A. Paczkowska, E. Starkel, Praca socjalna $w$ stużbie terminalnie chorym $i$ ich bliskim $w$ opiece paliatywno-hospicyjnej, in: Pozamedyczne aspekty opieki paliatywnohospicyjnej, J. Binnebesel, A. Janowicz, P. Krakowiak, A. Paczkowska (eds.), Gdańsk 2010, FH, p. 15.

35 Jan Paweł II, Adhortacja apostolska "Familiaris consortio" (22.11.1981), nr 26. 
the forms of support offered in the case of terminal illness is the hospice support of an interdisciplinary team ${ }^{36}$. Hospice support may prevent a lot of negative emotional effects of the child's illness, e.g. the child's sense of social isolation.

The family is considered to be an environment full of prospects for the child's adult life. One of the elements of creating developmental prospects is paying more attention to the religious dimension of family life ${ }^{37}$. Disregarding this aspect may lead to the destruction of this most basic cell of social life. John Paul II explained that "the link between secularization and the crisis of marriage and of the family is only too clear. The crisis concerning the meaning of God and that concerning moral good and evil has succeeded in diminishing an acquaintance with the fundamentals of marriage and of the family, which is rooted in marriage. For an effective recovery of the truth in this field, it is necessary to rediscover the transcendent dimension that is intrinsic to the full truth of marriage and the family, overcoming every dichotomy that tends to separate the profane aspects from the religious as if there were two marriages: one profane and another sacred" 38 .

The acknowledgment of the transcendental dimension of marriage and the family reveals new prospects for the family members. Faith enables them to experience a new quality of life. The uniqueness of family life based on religious values refers to God, who is the highest value. It is therefore necessary to arrange family relationships in the light of Revelation. The isolation of a child brought up in a family consciously experiencing the religious aspect of life with full awareness is significantly reduced.

\section{Conclusion}

A child's isolation in the family raises justified concerns. The variety of factors which may influence the sense of a child's isolation proves that the process of describing and counteracting social isolation is very complex. The

\footnotetext{
${ }^{36}$ M. Górecki, Geneza i rozwój opieki hospicyjnej - paliatywnej, in: Prawda umierania i tajemnica śmierci, M. Górecki (ed.), Warszawa 2010, Żak, p. 234-236.

37 J. Mastalski, Samotność globalnego..., op. cit., p. 511-512.

38 Jan Paweł II, Wymiar nadprzyrodzony związu małżeńskiego. Przemówienie do członków Roty Rzymskiej (30.01.2003), "L'Osservatore Romano" 4 (2003), p. 47.
} 
analysis of only two aspects of this phenomenon revealed the significance of family relationships in the process of social isolation. The quality of relationships between family members determines the integrity of the family and its ability to adapt to new, unexpected events.

It is necessary to support the families in which the sense of a child's isolation results from the parents' inadequate concern for the child's needs. Support may help the parents to recognize those needs and may motivate them to meet their child's expectations. In the case of isolation which is caused by illness, support must be interdisciplinary.

Action aimed at counteracting the child's isolation in the family should be based on values which enable the family members to form permanent, deep bonds. Support offered to a family which discovers its identity as resulting from the transcendental dimension of human existence should take those values into consideration.

\section{Bibliography}

Aasgaard T., Edwards M., Children expressing themselves, in: Oxford Textbook of Palliative Care for Children, A. Goldman, R. Hain, S. Liben (eds.), New York 2012, OU Press, p. 100-107.

Błasiak A., Obszary, możliwości i potrzeby pedagogicznego wspomagania rodziny $w$ dzisiejszej rzeczywistości, in: Dokąd zmierzasz wspótczesna rodzino?, M. Duda, A. Świerczek (eds.), Kraków 2012, Św. Stanisława BM, p. 317-347.

Błasiak A., Oddziaływania wychowawcze w rodzinie. Zagadnienia wybrane, Kraków 2012, WAM.

Bukowska M., Zagadnienie samotności we współczesnej polskiej literaturze naukowej, Kraków 2008, MCDN.

Izdebska J., Samotność dziecka, in: Encyklopedia pedagogiczna XXI w., T. Pilch (ed.), vol. 5, Warszawa 2006, Żak, p. 657-659.

Jan Paweł II, Adhortacja apostolska "Familiaris consortio" (22.11.1981).

Jan Paweł II, Wymiar nadprzyrodzony zwiazku małżeńskiego. Przemówienie do członków Roty Rzymskiej (30.01.2003), „L'Osservatore Romano” 4 (2003), p. 47-48.

Kawula S., Rodzina o skumulowanych czynnikach patogennych, in: Pedagogika rodziny. Obszary i panorama problematyki, S. Kawula, J. Brągiel, A. W. Janke, (eds.), Toruń 2007, Adam Marszałek, p. 135-172.

Lachowska B., Szczęśliwe dzieciństwo - uwarunkowania rodzinne, in: Oblicza dzieciństwa, D. Kornas-Biela (ed.), Lublin 2001, KUL, p. 273-283.

Maciarz A., Psychoemocjonalne $i$ wychowawcze problemy dzieci przewlekle chorych, Kraków 2001, IMPULS.

Mastalski J., Samotność globalnego nastolatka, Kraków 2007, PAT. 
Matyjas B., Źródta prowadzace do osamotnienia dziecka $w$ rodzinie, in: Wychowanie $w$ rodzinie. Rodzina o specjalnych potrzebach, S. Walasek, B. Winczura (eds.), Jelenia Góra 2011, KPSW, vol. 4, p. 127-137.

Olearczyk T. E., Sieroctwo i osamotnienie. Pedagogiczne problemy kryzysu wspótczesnej rodziny, Kraków 2010, WAM.

Pawłowska R., Jundziłł E., Pedagogika człowieka samotnego, Gdańsk 2000, GWSH.

Rembowski J., Samotność, Gdańsk 1992, UG.

Stala J., Rozpoznanie u początku prawidłowej pomocy - charakterystyka osób $z$ niepetnosprawnościa intelektualna, in: Socjalizacja - wyzwanie współczesności, J. Stala (ed.), Tarnów 2010, Biblos, p. 445-456.

Ziółkowska B., Dziecko chore $w$ domu, w szkole i u lekarza. Jak wspomagać rozwój dzieci przewlekle chorych, Gdańsk 2010, GWP.

Wywiad Benedykta XVI: pozytywna Ewangelia rodziny (18.08.2006), in:

www.radiovaticana.va (12.01.2014).

www.education.stateuniversity.com (09.01.2014).

www.nspcc.org.uk (09.01.2014). 